\title{
Suplementasi Ampas Teh Hijau Fermentasi pada Pakan terhadap Performa dan Income Over Feed Cost Itik Cihateup
}

\author{
Andri Kusmayadi ${ }^{1}$, Ristina Siti Sundari², Kamiel Roesman Bachtiar ${ }^{3}$ \\ ${ }^{1}$ Program Studi Peternakan, Fakultas Pertanian, Universitas Perjuangan \\ ${ }^{2}$ Program Studi Agribisnis, Fakultas Pertanian, Universitas Perjuangan \\ ${ }^{3}$ Program Studi Farmasi, Fakultas Ilmu Kesehatan, Universitas Perjuangan \\ 1,2,3 Jalan Pembela Tanah Air No. 177 Tasikmalaya, Jawa Barat, Indonesia \\ *Email Korespondensi: andrikusmayadi@unper.ac.id
}

(Diterima 17-05-2020; disetujui 18-09-2020)

\begin{abstract}
ABSTRAK
Ampas teh hijau merupakan salah limbah yang berasal dari rumah tangga maupun industri pengolah teh yang ketersediaannya cukup melimpah seiring tingginya konsumsi teh masyarakat Indonesia. Ampas teh hijau dilaporkan mengandung senyawa polifenol dengan kandungan antioksidan yang tinggi namun memiliki senyawa antinutrisi yaitu tanin yang dapat menghambat proses kecernaan nutrien. Tanin dapat diminimalisir dan dihilangkan kandungannya pada ampas teh melalui proses fermentasi sehingga kecernaan dapat ditingkatkan. Penelitian bertujuan untuk mengetahui pengaruh penambahan ampas teh hijau fermentasi (ATHF) terhadap performa (pertambahan bobot badan, konversi pakan, persentase karkas) dan income over feed cost itik Cihateup. Penelitian dilakukan secara eksperimen menggunakan rancangan acak lengkap. Sebanyak 60 ekor itik Cihateup berumur sehari dikelompokkan secara acak pada 4 kelompok perlakuan pakan yang disuplementasi dengan ATHF yaitu K0 (0\% ATHF), K1 (1\% ATHF), K2 (2\% ATHF), dan K3 (3\% ATHF). Data dianalisis menggunakan ANOVA dan apabila berbeda nyata diuji lanjut dengan metode Duncan's Multiple Range Test (DMRT). Penambahan ATHF pada pakan itik Cihateup menunjukkan perbedaan yang nyata pada parameter pertumbuhan bobot badan dan konversi pakan serta berbeda sangat nyata pada IOFC. Penambahan ampas teh hijau fermentasi pada level $1 \%$ memberikan dampak positif terhadap perbaikan pertambahan bobot badan, konversi pakan, dan IOFC.
\end{abstract}

Kata kunci: ampas teh, income over feed cost, imbuhan pakan,. teh fermentasi

\begin{abstract}
Green tea waste is one of the waste originating from households and the tea processing industry, whose availability is quite abundant in line with the high consumption of Indonesian tea. Green tea pulp is reported to contain polyphenol compounds with high antioxidant content but has an anti-nutrient compound namely tannins which can inhibit the process of nutrient digestion. Tannins can be minimized and their presence eliminated in tea waste through the fermentation process so that digestibility can be improved. The study aims to determine the effect of the addition of fermented green tea waste (ATHF) to growth performance (body weight gain, feed conversion, carcass percentage) and income over feed cost of Cihateup ducks. The research was conducted experimentally using a completely randomized design. Sixty-day-old Cihateup ducks were randomly grouped into 4 treatment groups supplemented with ATHF, namely K0 (0\% ATHF), K1 (1\% ATHF), K2 (2\% ATHF), and K3 (3\% ATHF). The data were analyzed using ANOVA and if they were significantly different, it was further tested using the Duncan's Multiple Range Test (DMRT) method. . The addition of ATHF in Cihateup duck feed showed significant differences in body weight gain parameters and feed conversion and was very significantly different in IOFC. The addition of fermented green tea waste at the level of $1 \%$ had a positive impact on improving body weight gain, feed conversion, and IOFC.
\end{abstract}

Keywords: feed additive, fermented tea, tea waste, income over feed cost 


\section{PENDAHULUAN}

Jawa Barat merupakan salah satu produsen teh terbesar di Indonesia dengan jumlah produksipada Tahun 2019 mencapai 92.962,02 ribu ton. Tasikmalaya merupakan salah satu produsen teh terbesar di Jawa Barat dengan luasan lahan mencapai 10.051,74 hektar (BPS Jawa Barat, 2018). Kondisi ini menunjukkan bahwa Tasikmalaya memiliki kontribusi yang besar dalam menyediakan teh di Jawa Barat sekaligus nasional. Jenis teh yang paling banyak dibudidayakan di Tasikmalaya yaitu teh hijau. Pabrik pengolah teh hijau di Tasikmalaya menghasilkan ampas teh yang berpotensi limbah karena belum dimanfaatkan dengan baik. Ampas teh hijau dilaporkan mengandung senyawa antioksidan kuat $(57.5 \mu \mathrm{g} / \mathrm{mL})$ dan total fenol yang tinggi (13.18 mg GAE/g) (Martono, 2010) sehingga dapat meningkatkan kesehatan tubuh (Samynathan et al., 2016).

Ampas teh masih mengandung senyawa polifenol (epigatokatekin galat, epikatekin galat, epigalokatekin dan epikatekin) serta flavonoid mycetin, quercetin dan kaempferol sehingga mengandung antioksidan kuat (Chusnie dan Lamb 2005; Tugiyanti et al., 2017). Lorenzo dan Monekata (2016) melaporkan bahwa teh hijau mengandung antosianidin, flavanon, flavanol, flavon, flavonol, dan isoflavon yang memiliki dampak positif terhadap kesehatan dan mencegah berbagai gangguan fungsi biologis tubuh. Ampas teh hijau berpotensi dijadikan sebagai imbuhan pakan unggas dengan kandungan bahan kering $93,59 \%$, bahan organik $88,08 \%$, protein kasar $19.63 \%$ dengan kandungan tannin dan serat kasar yang cukup tinggi masing-masing sebesar 7,91\% dan 17,40\% (Angga et al., 2018). Penambahan ampas teh hijau yang belum difermentasi belum mampu memperbaiki produksi karkas kelinci karena masih tingginya kandungan serat kasar (Wibowo et al., 2014). Kandungan tannin dan serat kasar yang tinggi dapat menghambat kecernaan nutrien sehingga perlu diproses terlebih dahulu, salah satunya melalui proses fermentasi.

Fermentasi menggunakan effective microorganism (EM4) dilaporkan mampu menurunkan kadar tanin pada Azolla microphylla (Melita et al., 2018) dan serat kasar kulit pisang (Triani, 2017). EM4 merupakan kultur campuran berbagai mikroorganisme yaitu bakteri fotosintetik, bakteri asam laktat, actinomycetes dan ragi (Has et al., 2017) dengan kemampuannya yang efektif dalam mendegradasi serat kasar serta memperbaiki rasa dan aroma pakan (Putra et al., 2019) sehingga kecernaan dan nafsu makan meningkat. Ampas teh berpotensi dijadikan sebagai bahan baku pakan itik karena masih mengandung nutrien yang lengkap dengan kandungan protein yang cukup tinggi yaitu sebesar 27,42\%. Pemanfaatan ampas teh hijau pada level 5\% memiliki dampak negatif terhadap pertumbuhan dan penampilan ayam broiler karena mengandung asam tanin yang tinggi (Tugiyanti $e t$ al., 2017). Ampas teh hijau fermentasi yang ditambahkan pada pakan itik Cihateup pada level lebih rendah diharapkan dapat memperbaiki pertambahan bobot badan, konversi pakan, persentase karkas dan IOFC.

\section{MATERI DAN METODE}

\section{Materi Penelitian}

Itik Cihateup berumur 1 hari, ampas teh hijau yang didapatkan dari pabrik pengolah teh di Kecamatan Taraju Kabupaten Tasikmalaya, air minum, mineral, vitamin, tempat pakan dan tempat minum, bahan pakan basal, kandang kelompok sebanyak 15 petak dan timbangan digital.

\section{Proses Pengolahan Ampas Teh Hijau Fermentasi}

Ampas teh berbentuk daun dipotong kecilkecil kemudian difermentasi dengan formula: sebanyak $1000 \mathrm{~g}$ ampas teh hijau ditambahkan dengan $100 \mathrm{ml}$ air bersih, $5 \mathrm{ml}$ EM 4 dan $5 \mathrm{ml}$ molases. Fermentasi ampas teh hijau dilakukan secara anaerob (tertutup) selama 1 minggu pada suhu $21-25^{\circ} \mathrm{C}$. Ampas teh hijau yang sudah difermentasi selanjutnya dicampurkan ke dalam pakan itik Cihateup dengan formulasi $0 \%, 1 \%, 2 \%$ dan $3 \%$.

\section{Metode Penelitian}

Penelitian menggunakan 60 ekor itik cihateup jantan umur sehari yang dipelihara selama 56 hari dan dikelompokkan ke dalam 4 kelompok perlakuan pakan yaitu: R1 (100\% pakan basal/PB tanpa penambahan ATHF), R2 (PB + 1\% ATHF), $\mathrm{R} 3$ (PB + 2\% ATHF) dan R4 (PB + 3\% ATHF), masing-masing diulang sebanyak 5 kali ulangan. Perlakuan pemberian ampas teh hijau fermentasi dilakukan melalui ransum pakan yang dimulai pada hari ke 15 hingga hari ke 56.

\section{Parameter yang diukur}

Parameter yang diukur terdiri atas performa yang meliputi pertambahan bobot badan, konversi pakan dan persentase karkas, serta income over feed cost (IOFC). Pertambahan bobot badan diukur dengan cara menghitung selisih bobot hidup akhir pada periode tertentu dengan bobot hidup sebelumnya. Konversi pakan diukur dengan cara 
membandingkan jumlah pakan yang dikonsumsi pada waktu tertentu dengan pertambahan bobot hidup yang dihasilkan pada waktu itu pula. Persentase karkas diperoleh dengan cara membagi bobot karkas dengan bobot potong (bobot badan sebelum itik dipotong) dikalikan $100 \%$. Income Over Feed Cost (IOFC) dihitung dengan cara menghitung selisih hasil penjualan itik dengan jumlah biaya pakan selama pemeliharaan.

\section{Analisis Data}

Data yang diperoleh diolah dengan menggunakan analisis sidik ragam dan apabila terdapat perbedaan nyata dilanjutkan dengan uji Duncan's Multiple Range Test (DMRT) dengan bantuan perangkat lunak SPSS versi 25.0.

\section{HASIL DAN PEMBAHASAN}

Hasil uji performa yang terdiri atas pertambahan bobot badan, konversi pakan dan persentase karkas serta income over feed cost (IOFC) itik cihateup disajikan pada Tabel 2. Hasil uji statistika pertambahan bobot badan harian itik cihateup (Tabel 1) menunjukkan bahwa perlakuan K0 berbeda nyata dengan K1, K2 dan K3. Kondisi ini menunjukkan bahwa pertambahan bobot badan harian pada perlakuan kontrol berbeda dengan kelompok perlakuan pakan yang ditambahkan ampas teh hijau fermentasi. Perlakuan K1 dan K2 yang mengandung $1 \%$ dan $2 \%$ ATHF terbukti dapat memperbaiki pertambahan bobot badan harian itik Cihateup dibandingkan K0 (25,05 g dan 26,33 g VS 23,02 g). Hal ini disebabkan perlakuan K1 dan K2 mengandung senyawa katekin pada level optimal sehingga berpengaruh dalam memperbaiki pertambahan bobot badan. Senyawa katekin pada teh hijau dilaporkan memiliki aktivitas antioksidan yang sangat kuat yang bermanfaat bagi kesehatan tubuh dengan cara mengerahkan kapasitas antioksidannya terhadap reaksi oksidatif dengan mengurangi konsentrasi oksigen lokal, menghindari inisiasi reaksi berantai dengan menangkap radikal, mencegah generasi radikal dan memecah peroksida lipid menjadi radikal (Lorenzo \& Munekata, 2016). Mekanisme pencegahan radikal bebas tersebut menyebabkan kesehatan itik menjadi terjaga dan terhindar dari stress oksidatif.

Terjadinya peningkatan pertambahan bobot badan yang ditemukan pada perlakuan K1 dan K2 diduga berkorelasi positif dengan semakin efektifnya penyerapan nutrien pada usus itik. Khan (2014) melaporkan bahwa senyawa bioaktif pada teh hijau mampu memperbaiki mikroflora usus dengan cara menurunkan total bakteri, membunuh bakteri patogen dan menurunkan $\mathrm{pH}$ pada sekum broiler sehingga penyerapan nutrient menjadi meningkat. Semakin meningkatnya penyerapan nutrient tersebut menyebabkan asupan asam amino meningkat sebagai prekursor pembentukan daging sehingga proses pembentukan daging lebih baik yang tercermin pada meningkatnya pertambahan bobot badan perlakuan K1 dan K2.

Hasil uji statistika konversi pakan menunjukkan bahwa perlakuan pakan K1 berbeda nyata dengan K0. Keadaan ini menunjukkan bahwa perlakuan pakan yang mengandung $1 \%$ ampas teh hijau fermentasi mampu memperbaiki konversi pakan dibandingkan kontrol (5,19 VS 6,09). Hal ini menunjukkan bahwa perlakuan K1 terbukti lebih efisien dalam mengkonversi pakan menjadi daging dibandingkan kontrol. Kondisi ini sejalan dengan penelitian lain bahwa penambahan teh hijau pada broiler dengan dosis 0,5-1,5\% mampu memperbaiki FCR broiler (Biswas \& Wakita, 2001; Khan, 2014). Hal ini terdapat korelasi dengan parameter pertumbuhan bobot badan (PBB) bahwa perlakuan K1 secara linear menunjukkan pertambahan bobot badan harian dan konversi pakan yang paling baik. Konversi pakan diperoleh dari nilai konsumsi pakan yang dibandingkan dengan pertambahan bobot badannya. Semakin kecil nilai konversi pakan menunjukkan semakin efisien pakan yang dikonversi menjadi daging. Perlakuan K1 diduga memiliki kandungan senyawa bioaktif dalam jumlah yang optimal yang berdampak secara langsung terhadap penggunaan nutrient tersebut untuk produksi (daging). Hal ini disebabkan oleh senyawa katekin terutama epigalokatekin galat yang diduga mampu memperbaiki efisiensi pakan (Hrnčár \& Bujko, 2017).

Tabel 2. Hasil uji performa dan income over feed cost (IOFC) itik cihateup

\begin{tabular}{ccccc}
\hline Perlakuan & PBB $(\mathrm{g})^{*}$ & Konversi Pakan* & $\begin{array}{c}\text { Persentase Karkas } \\
(\%)\end{array}$ & $\begin{array}{c}\text { IOFC } \\
(\text { Rupiah)** }\end{array}$ \\
\hline K0 (0\% ATHF) & $23,02+3,17^{\mathrm{ab}}$ & $6,09+0,14^{\mathrm{b}}$ & $63,59+17,27$ & $4190,96+1089,63^{\mathrm{a}}$ \\
K1 (1\% ATHF) & $25,05+1,43^{\mathrm{b}}$ & $5,19+0,12^{\mathrm{a}}$ & $62,72+7,09$ & $7251,30+1598,46^{\mathrm{c}}$ \\
K2 (2\% ATHF) & $26,33+1,79^{\mathrm{b}}$ & $5,76+0,07^{\mathrm{ab}}$ & $63,68+8,96$ & $5146,96+685,42^{\mathrm{b}}$ \\
K3 (3\% ATHF) & $21,07+2,64^{\mathrm{a}}$ & $5,90+0,10^{\mathrm{ab}}$ & $59,62+12,03$ & $3813,66+997,49^{\mathrm{a}}$ \\
\hline
\end{tabular}

Keterangan: *Superskrip yang berbeda pada kolom yang sama menunjukkan perbedaan yang nyata $(\mathrm{P}<0,05)$ **S Superskrip yang berbeda pada kolom yang sama menunjukkan perbedaan yang sangat nyata $(\mathrm{P}<0,01) ; \mathrm{PBB}=$ pertumbuhan bobot badan . 
Hasil uji statistika persentase karkas tidak menunjukkan perbedaan yang nyata $(\mathrm{P}>0,05)$ pada semua perlakuan. Kondisi ini menunjukkan bahwa persentase karkas pada semua perlakuan sama dan tidak dipengaruhi oleh penambahan ampas teh hijau fermentasi. Hal ini sejalan dengan penelitian (Hrnčár \& Bujko, 2017) bahwa penambahan ampas teh fermentasi pada ayam broiler tidak mempengaruhi persentase karkas namun memperbaiki persentase bagian karkas yaitu meningkatkan persentase paha dan menurunkan persentase sayap (Biswas \& Wakita, 2011; Khan, 2014).

Nilai IOFC menunjukkan selisih total pendapatan dengan biaya ransum yang digunakan selama pemeliharaan. Hasil uji statistika (Tabel 1) menunjukkan bahwa perlakuan K1 dan K2 menghasilkan IOFC yang berbeda sangat nyata dengan K0. Penambahan ampas teh hijau fermentasi pada level $1 \%$ dan $2 \%$ menghasilkan IOFC yang lebih baik dibandingkan kontrol. IOFC memiliki korelasi positif dengan pertambahan bobot badan dan konversi pakan karena pertumbuhan yang baik dan diikuti dengan konversi pakan yang baik serta biaya pakan yang yang minimal akan mendapatkan keuntungan yang maksimal pula (Suprayogi et al., 2017). Hasil penelitian ini menunjukkan bahwa perlakuan K1 memiliki pertambahan bobot badan dan efisiensi pakan yang tinggi serta biaya pakan yang rendah sehingga menghasilkan keuntungan yang paling besar. Semakin efisien ternak dalam mengubah zat makanan menjadi daging maka semakin baik pula IOFC yang dihasilkan (Mayora et al., 2018).

\section{KESIMPULAN}

Penambahan ampas teh hijau fermentasi berpengaruh nyata terhadap pertambahan bobot badan, konversi pakan, dan IOFC itik Cihateup. Penambahan ampas teh hijau fermentasi pada dosis $1 \%$ memiliki pengaruh yang lebih baik dibandingkan perlakuan lainnya.

\section{DAFTAR PUSTAKA}

Angga, I.W.A., Rizal, Y., Mahata, M.E., Yuniza, A., \& Mayerni, R. 2018. Potential of waste tea leaves (camellia sinensis) in west sumatra to be processed into poultry feed. Pakistan Journal of Nutrition 17:287-293

Badan Pusat Statistik. 2020. Provinsi Jawa Barat dalam Angka 2020. BPS Provinsi Jawa
Barat.

Biswas, A.H. \& Wakita, M. 2001. Comparison of two dietary factors, green tea powder feeding and feed restriction, influencing laying performance and egg quality in hens. Bulletin of the Faculty of Bioresources, Mie University 25-26:5561.

Cushnie, T.P. \& Lamb Andrew J. 2005. Antimicrobial activity of flavonoids. International Journal of Antimicrobial Agents 26(1):343-356.

Has, H., A. Indi, \& M.A. Pagala. 2017. Karakteristik nutrien kulit pisang sebagai pakan ayam kampung dengan perlakuan pengolahan pakan yang berbeda. Prosiding Seminar Nasional Riset Kuantitatif Terapan. Fakultas MIPA Univeristas Halu Oleo. Kendari, 8 April 2017. Hlm: 41-45.

Hrnčár, C. \& J. Bujko. 2017. Effect of different levels of green tea (camellia sinensis) on productive performance, carcass characteristics and organs of broiler chickens. Potravinarstvo Slovak Journal of Food Sciences 11(1):623-628.

Khan, S.H. 2014. The use of green tea (Camellia sinensis) as a phytogenic substance in poultry diets. Onderstepoort Journal of Veterinary Research 81(1):e1-e8. DOI: 10.4102/ojvr.v81i1.706.

Lorenzo, J.S. \& P.E.S. Munekata. 2016. Phenolic compounds of green tea: Health benefits and technological application in food. Asian Pacific Journal of Tropical Biomedicine 6(8):709-719.

Martono, Y. 2010. Potency of industrial tea waste: Comparison between green and black tea industrial wastes as uv filter for sunscreen. Indonesian Journal of Cancer Chemoprevention 1(1):54-59

Melita, S.N., Muryani, R. \& Mangisah, I. 2018. The effect of Azolla microphylla fermented powder in the diet to use protein of crossbreed native chicken. Jurnal Peternakan Indonesia 20(1):8 -14.

Putra, G.Y., Sudarwati, H. \& Mashudi, M. 2019. Effect of addition banana peel (Musa paradisiaca L.) fermentation in a complete feed on the nutrient contents 
and digestibility by in vitro. Jurnal Nutrisi Ternak Tropis 2(1):42-52.

Mayora, W.I., Tantalo, S., Nova, K. \& Sutrisna, R. 2018. Performa ayam KUB (kampung unggul balitnak) periode starter pada pemberian ransum dengan protein kasar yang berbeda. Jurnal Riset dan Inovasi Peternakan 2(1):26-31.

Samynathan, R., S.K. Perisamy, S. Gandhi, J. Anitha, G. Sanmugam, M. Padmanabhan \& G.V. Kanniappan, 2016. Biochemical and molecular analysis of Camellia sinensis (L.) O. Kuntze tea from the selected P/11/15 clone. J. Genet. Eng. Biotechnol 14:69 75 .

Suprayogi, W.P.S., Sudibyo, S. \& Susilo, E.H. 2017. Performa itik lokal jantan (Anas plathyrynchos) yang diberi pakan suplemen. Caraka Tani: Journal of Sustainable Agriculture 32(1):35-41.

Triani, H.D. 2017. Pengaruh pemberian biji alpukat dan kulit pisang fermentasi terhadap berat serta warna kuning telur puyuh. Jurnal Bibiet 2(2):60-67.

Tugiyanti, E. E. Susanti, \& I.H. Sulistyawan. 2017. Review: Pemanfaatan ampas teh sebagai feed aditif pakan unggas dan anti bakteri terhadap Escherichia coli. Prosiding Seminar Teknologi dan Agribisnis Peternakan V, Fakultas Peternakan Universitas Jenderal Soedirman. Purwokerto, 18 November 2017. Hlm: 54-62.

Utami, T.S., Sulistyawan, I.H. \& Tugiyanti, E. 2018. Supplementation of fermented tea waste in diets on final body weight and carcass percentage of male quails. Journal of Livestock and Animal Production 1(1):48-53.

Wibowo, R.Y., Riyanto, J. \& Subagyo, Y.B.P. 2014. Effect of tea dregs (Camellia sinensis) in rations on carcass production of New Zealand White male rabbits. Biofarmasi 12(1):11-17. DOI: 10.13057/biofar/f120102. 